\title{
Ecohydrology of the Save Valley Conservancy in Zimbabwe: Initial insights into freshwater pan formation
}

\author{
Gaathier Mahed ${ }^{1}$, Luc Brendonck ${ }^{2}$, Tamuka Nhiwatiwa ${ }^{3}$, and Never Mujere ${ }^{3}$ \\ ${ }^{1}$ Nelson Mandela Metropolitan University \\ ${ }^{2}$ University College Leuven-Limburg \\ ${ }^{3}$ University of Zimbabwe
}

January 20, 2022

\begin{abstract}
Temporary freshwater pools or pans are known for their nature value and socio-economic importance especially in arid and semiarid regions, but it is still poorly known how they develop in a natural setting. The ecologically valuable temporary freshwater pans of the Save Valley Conservancy in Zimbabwe, are studied in order to gain insights into their formation. Field observations of 17 existing pans and in situ measurements at one possible site of pan formation were done. It was observed that in most cases trees were bordering existing pans with Diospyros mespiliformis being present at eight locations and Colophospermum mopane at five. These two species were co-existing at two locations which had also dead trees present. On the basis of these observations, a suspected developing pan was followed up using hydrological field observations to understand processes that are important in pan formation. In situ infiltration tests as well as penetrometer tests, before and after a rainfall event, were completed on a grid covering $25 \mathrm{~m} 2$. The measurements were taken at one-metre interval and the data were krigged in order to visualise the contours. Initial insights point towards the areas in the immediate vicinity of trees acting as preferential pathways for infiltration, which is in contrast to what is needed for ponding. Based on these findings, we propose a possible theory for the formation of pans in the study area and suggest techniques for monitoring pan formation.
\end{abstract}

\section{INTRODUCTION}

Pans are temporary aquatic formations which normally occur in arid and semi-arid environments (Goudie, 1991). These temporary desert depressions are extensively documented at a global scale (Goudie and Wells (1995). The term 'pan' is of South African origin which refers to a flat, sediment-filled depression that holds water periodically (Davies and Day, 1998). This term will be used in this study to differentiate rain pools of southern Africa from other types of temporary pools and ponds.

The major drivers for pan formation in arid areas include; lack of fluvial integration; deflation of the surface; limited sand; accumulation and infilling; weathering of the surface, suitable stratum and geological structure, (Marshall and Harmse, 1992; Goudie and Wells, 1995). Lancaster (1977) noted that dunes occur towards the south of the majority of pans in the Southern Kalahari, Botswana. This adds another dimension and needs to be explored in order to understand the impact the pan has on dunes and vice versa. It was previously thought that pan location is erratic and random in nature. However, Wormald et al (2003) has shown that, on a larger scale, geological structural features play a critical role in pan formation and location in southern Kalahari. Verhagen (1990) proposed an ecohydrological model, which highlighted erosion from animals as the major cause for pan formation in Botswana. It should be noted that other ecological factors were not considered in the past. Thus, the role that flora and fauna play in pan formation is poorly understood. Therefore, the processes leading to pan formation are not well known from an ecohydrological perspective.

Seasonal pans are the most common type of temporary pools in the lowveld regions of Zimbabwe. Besides 
temporary aquatic habitats that are directly connected to rivers during flooding, an important category of temporary lentic water bodies is unconnected and has an autonomous hydrology. This variation in dependency on rivers results in two main groups of pans, namely; endorheic and floodplain pans. Endorheic pans have an inward drainage system and depend on local rainfall and run-off whilst floodplain pans are depressions along river banks that are seasonally inundated during flooding. Basins with an autonomous hydrology are defined as endorheic systems and are generally the most abundant type of temporary pools. (Davies and Day, 1998).

The hydrological regime of the pans, and the processes related to their formation, in the Save Valley conservancy are not little known. It becomes critical to understand the hydrodynamics of this region, due to its important role in ecological diversity (Nhiwatiwa et al., 2011). This means that exploratory work is required in order to better understand the processes dictating pan formation, pan evolution as well as pan hydrodynamics. The ecology of these temporary pans has been extensively studied and some environmental variables have been explored by Nhiwatiwa et al. (2009). It has been shown that vegetation cover, hydraulic connectivity between surface water bodies and pool depth are major factors determining the biodiversity within pan ecosystems.

\section{MATERIALS AND METHODS}

\subsection{Description of study area}

The Save Valley Conservancy is situated to the semi-arid south east lowveld of Zimbabwe (Figure 1). It covers an area of $3,442 \mathrm{~km}^{2}$ and is the largest co-operatively managed wildlife reserve in the world. Multiple properties in the conservancy are held by private ranchers, local councils, government and the surrounding community (Lindsey et al., 2008; Nhiwatiwa et al., 2011). The conservancy is bordered by communal land whose population densities lie between 11 and 82 people per $\mathrm{km}^{2}$, with some commercial agriculture to the south and east (Pole, 2006; Lindsey et al., 2008)

\section{INSERT FIGURE 1 HERE}

FIGURE 1. Location of Save Valley Conservancy in Zimbabwe

The plain to the west of the Save River is populated with small to large pans (Figure 2). These pans fill up on seasonal basis and activate a unique ecosystem (Nhiwatiwa et al., 2014).

\section{INSERT FIGURE 2 HERE}

FIGURE 2: Distribution of pans (dots) west of Save River in Save Valley Conservancy

Save Valley Conservancy lies at an average elevation of $620 \mathrm{~m}$ above sea level (Figure 3). It is underlain by granite, gneiss and paragneiss with scattered buttes throughout the gently undulating landscape (Goodwin et al., 1997). Soils are generally of poor-quality and deciduous woodland savanna dominates the area. The conservancy receives low and variable rainfall, ranging from $474-540 \mathrm{~mm}$ per annum (Lindsey et al., 2008).

\section{INSERT FIGURE 3 HERE}

FIGURE 3. Variation of elevation in the Save Valley Conservancy.

The riparian areas are prone to flooding which deposit alluvial sands and silts along river banks. This irregular deposition combined with low lying areas aid in the formation of pans which store water on seasonal basis (Figure 4).

\section{INSERT FIGURE 4 HERE}

FIGURE 4: Cross section of the Suni pan highlighting the subsurface geology

\subsection{Experimental methods}

Field observations formed the cornerstone of the methodology in this study to understand and characterise the pans in the study area. A total of 17 pans were studied with regards to their immediate environmental 
settings. Of particular importance was the orientation of the closest tree, as trees are suspected to initiate pan formation. Furthermore, soil hydraulic conductivity tests were undertaken in the immediate vicinity of trees with possibility of pan formation. These tests were completed using a Decagon ${ }^{\circledR}$ Mini disk infiltrometer which shows the pressure under which soil absorbs water. The cumulative infiltration during the test was measured and recorded. Lastly, two sets of penetrometer readings were taken in the vicinity of the trees during field trip. The first set of readings was completed prior to the first rainfall event while the second set of tests were done after the rainfall event. The data from the infiltration and penetrometer tests were gridded and kriged in order to create contour plots.

\section{RESULTS}

Field observations of the 17 study pans indicate that the majority of pans lie east or north east of nearby trees. These positions are shaded zones in the late afternoon (Figure 5).

\section{INSERT FIGURE 5 HERE}

FIGURE 5: The orientation of pans in relation to trees within the Save Valley Conservancy $(\mathrm{n}=17)$

The tree species in the immediate vicinity of pans during formation were identified as Diospyros mespiliformis and Colophospermummopane. Diospyros mespiliformis was also present at eight fully developed pans. Colophospermum mopane was observed at five locations. Both species co-occurred at two sites. Field survey observed two sites with dead trees in the immediate vicinity of pans. The predominance of Diospyros mespiliformis, as well as pan orientation in relation to presence of trees (Figure 3), points towards a distinct relationship between pans and trees in the study area.

Kriged infiltration data on pan formation highlight preferentially high areas for infiltration in the immediate vicinity of trees (Figure 6). The penetrometer readings after rainfall event also alludes to the aforementioned fact. By comparing the penetrometer readings before and after rainfall, it was observed that rainfall has a direct impact on the hardness of the soil.

\section{INSERT FIGURE 6 HERE}

FIGURE 6: The grid (A) and krigged penetrometer (B and C) as well as cumulative infiltration measurements (D) for the area studied in the immediate vicinity of a possible pan in formation. The units B and C are $\mathrm{kg} / \mathrm{cm}^{2}$, whilst $\mathrm{D}$ is in $\mathrm{cm} / \mathrm{s}$.

\section{DISCUSSION}

We performed a preliminary study to better understand pan formation in Save Conservancy in Zimbabwe. We studied the landscape setting of natural pans and followed up a suspected pan in formation. The presence and orientation of trees at most pans suggests a distinct relationship between trees and pans. The orientation of pans in relation to trees highlights the importance of shade in pan formation as it minimises evapotranspiration (de Vries et al., 2011).

Our fieldwork data point towards preferential infiltration occurring during the initial stages of pan formation. The shape of the preferential flow area is distinctly similar to that of a pan. The location of pans in tree shadows further alludes to the importance of trees in pan formation. Shaded areas beneath trees are also vital for animal congregation in the late afternoon towards east of trees. Goudie and Wells (1995) show that animals play a major role in pan formation in arid regions of the world by aiding deflation of surface or erosion.

Our field observations in the study area indicate that the following prerequisites are critical for pan formation:

1. One or more trees are required in order to provide shade, particularly in the late afternoons towards the east.

2. Animals that act as eroding agents in the immediate vicinity of the tree, particularly by congregating to the east of trees in the late afternoon. 
3. The eroded area needs to fall within the drainage system in order for water to be supplied to form the pan. In addition, there is possibility of groundwater discharging into the pan.

4. The drainage system transports sediments along channels and deposits them along preferential pathways towards the pans.

5. Fine sediments form layers on the base of the pan limiting infiltration and promoting ponding of water on temporary basis.

In contrast to the last point (number 5), our measurements revealed the forming depression in the shaded zone as a point of preferential infiltration (Figure 3). A prolonged period of time might be needed in order for the deposition of clay to accumulate to levels where infiltration is minimized and ponding can occur. This is important as clays have the lowest infiltration rate among all soil types (Davie, 2008). Shaw (1988) has shown that most soil moisture stems from rainfall. Thus, amount of rainfall has major implications on runoff, infiltration and surface processes, including the deposition of clay (Davie, 2008).

This distinct roles of fauna, flora and soil and hydrological processes are critical for the formation of pans. Thus, their role in pan formation needs to be understood and studied in order to verify this hypothesis on a larger scale. To understand better the spatial distribution of major hydrological processes and connectivity between pans, we recommend that isotopic finger printing of water and soil in pans, rivers as well as in terrestrial environments needs to be done. Observations should be done in the initial phases of the wet season in order to minimise the effect of evaporation on isotopic signatures. Sampling exercise should be completed over multiple years to cover the temporal dynamics of the system.

The use of remote sensing could also aid in better understanding of pan formation at a large spatial scale. Goudie (1991) has shown how this technique is critical in understanding large scale regional hydrological process dynamics which contribute to pan formation and maintenance. Wormald et al. (2003) have also shown how spatial analysis, in conjunction with remote sensing, aid in gaining insights into emplacement mechanisms of pans. Hence, multiple remote sensing tools be used to gain insights into spatial and temporal dynamics of pan formation (Meijerink, 2007). This will include, but not be limited to: soil moisture; evapotranspiration; surface deflation; digital elevation modeling; gravity; and surface hydrology.

A multitude of tools exist in order to complete a study of this nature. One such tool is the use of Gravity Recovery and Climate Experiment (GRACE) satellite data which provide long term total groundwater water storage over large areas. When using satellite products, a major challenge is to select the correct tool/tools taking into consideration the resolution, as well as spatial and temporal variability of the chosen satellite sensor. Despite all these issues, it is still an avenue that needs to be explored, due to hydrological data scarcity in arid and semi-arid environments like Save Valley Conservancy. The use unmanned aerial vehicles (UAVs) to target areas of interest, or where a higher resolution is required is a good option.

\section{CONCLUSION}

In this study, we highlighted the landscape setting of natural pans in Save Valley Conservancy in Zimbabwe. We then selected a possible location where a pan could be formed. Hydrological processes that could be important in pan development were explained. Our results and hypothesis on pan formation should be further elaborated by large-scale monitoring studies over extended durations.

\section{Acknowledgements}

We would have to thank the Flemish University Council (VLIR-UOS), for graciously funding the North South project. Also, the students and lecturers from KU Leuven, University of Zimbabwe and the University of the Western Cape are acknowledged for their input, support and constructive criticism. The support from Iphakade is greatly appreciated.

\section{References}

Abdel Galil, M. \& El-Fargany, E. (2011). Sedimentological significance and Brine Chemistry of recent coastal Sabkhas. Journal of King Abdullah University: Marine Sciences, 22 (2), 135-158. 
Davie, T. (2008). Fundamentals of Hydrology(2 ${ }^{\text {nd }}$ Ed.). London, Routledge.

Davies, B. \& Day, J. (1998). Vanishing waters . University of Cape Town Press, Cape Town, Republic of South Africa.

de Vries, T.T., Cochrane, T.A., Talia'uli, A.L. \& Kilgour, R.F.T. (2011). Influence of wind breaks and shade on evapotranspiration. Proceedings of the World Environmental and Water Resources Congress, 22-26 May, Palm Springs, California, American Society of Civil Engineers.

Goodwin, H.J., Kent, I.J., Parker, K.T. \& Walpole, M.J. (1997). The southeast lowveld, Zimbabwe. Volume IV. Final Report to the Department for International Development, pp. 248-253.

Goudie, A.S. (1991). Pans. Progress in Physical Geography ,15 (3), 221-237.

Goudie, A.S. \& Wells, G.L. (1995). The nature, distribution and formation of pans in arid zones. Earth Science Reviews ,38 , 1-69.

Lancaster, I.N. (1977). The pans of the Southern Kalahari, Botswana. (PhD thesis), United Kingdom, Cambridge University. https://doi.org/10.17863/CAM.16434

Lindsey, P.A., Du Toit, R., Pole, A. \& Romañach, S. (2008). Save Valley Conservancy: A large scale experiment in co-operative wildlife management. In B. Child, H. Suich \& A. Spenceley (Eds.), Evolution and Innovation in wildlife conservation in Southern Africa ( pp. 181-202). UK, Earthscan Publishers.

Marshall, T.R. \& Harmse, J.T. (1992). A review of the origin and propagation of pans. South African Geographer, 19, 9-21.

Meijerink, A.M.J. (2007). Remote Sensing Applications to groundwater . Paris: UNESCO

Moyo, S., O'Keefe, P. \& Sill, M. (1993). The Southern African Environment. Profiles of SADC countries. London, Earthscan Publications

Nhiwatiwa, T., de Bie, T., Vervaeke, B., Barson, M., Stevens, M., Vanhove, M.P.M. \& Brendonck, L. (2009). Invertebrate communities in dry season pools of a large subtropical river: patterns and processes.Hydrobiologia , 630, 169-186.

Nhiwatiwa, T., Brendonck, L., Waterkyn, A. \& Vanschoenwinkel, B. (2011). The importance of landscape and habitat properties in explaining instantaneous and long-term distributions of large branchiopods in subtropical temporary pans. Freshwater Biology, 56,1992-2008.

Nhiwatiwa, T., Waterkyn, A., Riddoch, B.J. \& Brendonck, L. (2014). A hotspot of large branchiopod diversity in south-eastern Zimbabwe.African Journal of Aquatic Science, 39, 57-65.

Pethick, J.S. (1974). The distribution of salt pans on tidal marshes. Journal of Biogeography , 1, 57-62.

Pole, A. (2006). Management plan for the Save Valley Conservancy . Unpublished report, Harare, Zimbabwe.

Schulz, S., Horovitz, M., Rausch, R., Michelsen, N., Mallast, U., Kohne, M., Siebert, C., Schuth, C., AlSaud, M. \& Merz, R. (2015). Groundwater evaporation from salt pans: Examples from the eastern Arabian Peninsula. Journal of Hydrology , 531, 792-801

Shaw, E.M. (1988). Hydrology in Practice ( $2^{\text {nd }}$ Ed.). London, T.J. Press.

Verhagen, B.T. (1990). On the nature and genesis of pans: A review and an ecological model. In: K. Heine (Ed), Paleoecology of Africa(pp. 179-194). Rotterdam, A.A. Balkema Publishers.

Wormald, R.J., Eckardt, F.D., Vearncombe, J. \& Vearncombe, S. (2003). Spatial distribution of pans in Botswana: The importance of structural control. South African Journal of Geology, 106, 287-290.

Yechieli, Y. \& Wood, W.W. (2002). Hydrogeologic processes in saline systems :playas, sabkhas and saline lakes. Earth Science Reviews ,58, 343-365 


\section{Hosted file}

Figure 1.docx available at https://authorea.com/users/456393/articles/553453-ecohydrology-ofthe-save-valley-conservancy-in-zimbabwe-initial-insights-into-freshwater-pan-formation

\section{Hosted file}

Figure 2.docx available at https://authorea.com/users/456393/articles/553453-ecohydrology-ofthe-save-valley-conservancy-in-zimbabwe-initial-insights-into-freshwater-pan-formation

\section{Hosted file}

Figure 3.docx available at https://authorea.com/users/456393/articles/553453-ecohydrology-ofthe-save-valley-conservancy-in-zimbabwe-initial-insights-into-freshwater-pan-formation

\section{Hosted file}

Figure 4.docx available at https://authorea.com/users/456393/articles/553453-ecohydrology-ofthe-save-valley-conservancy-in-zimbabwe-initial-insights-into-freshwater-pan-formation

\section{Hosted file}

Figure 5.docx available at https://authorea.com/users/456393/articles/553453-ecohydrology-ofthe-save-valley-conservancy-in-zimbabwe-initial-insights-into-freshwater-pan-formation

\section{Hosted file}


Figure 6.docx available at https://authorea.com/users/456393/articles/553453-ecohydrology-ofthe-save-valley-conservancy-in-zimbabwe-initial-insights-into-freshwater-pan-formation 